\title{
THE CONCEPT OF THE POLARIZED SPACE FORMATION IN THE ECONOMY OF THE REGION WITH RESOURCE POTENTIAL
}

\author{
Nadiia PYSAR ${ }^{1}$ \\ Vasyl Stefanyk Precarpathian National University, Ukraine
}

\begin{abstract}
The article analysed and systematized the theory and the paradigm of regional development. Opportunities for the optimum development of the regional economy in Ukraine are identified because the functioning of the market system is accompanied by crisis phenomena and requires deep scientific study of the contemporary economic theory and practice of going out of the crisis using the latest concepts of region development. Polarized space concept in the economy of the regions of Ukraine with the identifying of measures for its implementation is an important and insufficiently developed scientific research. The result of the transformation of economic transitions in the national economy is the dominance of so-called "point development". Despite the positive effect of the presence of the growth poles in a separate area, this situation reinforces the asymmetry in economic development in comparison with the other regions. A result of this is the differentiation of the main economic and social indicators of regional economic development. In this regard, the study of regional concepts and theories of regional economic development is urgent theoretical and practical task, because the lack of a unified approach to the foundations of the theory of economic space, and especially its regional component, does not allow to start solving some of the practical issues of systematic formation of common economic space of the country. These issues raise many questions of applied character, which economic theory may not always give a definite answer. Such questions are certainly of theoretical interest but, most importantly, their answers can contribute to the formation of an effective competitive economy in the region. The object of the study is the regions of Ukraine, with their resource potential and absence of a polarized space. The main objective is the formation on this basis of anti-crisis measures of region development. The subject of research is theoretical principles and methodology of formation of a polarized space with the low quality of economic space. The methodological base of this research is the dialectical method of cognition, systemic approach, fundamental provisions of economic theory and the theory of the polarized space. The following research methods are applied: logical generalization, systemic and structural analysis, comparison, statistical, expert, etc. The aim is to study the imperatives for the effective development of the locally-spatial system, taking into account its resource potential, determination of possible ways of its implementation with the aim of regional economic space development and ensuring strategic guidelines and goals for socio-economic development. The obtained results gave a possibility to determine necessary methodological bases of the improvement of regional development, to focus on the most influential directions in the theory of the economic development of a region, to substantiate the conceptualization of an optimal model of economic development of the region.
\end{abstract}

Key words: region, theory, concept, economic process, economic space, resource potential, socio-economic system, region, spatial localization, group of the imperatives.

JEL Classification: L51, Q42, R13

\section{Introduction}

Since the second half of the twentieth century, the development of the national economy depends on the processes of integration and regionalization. The increasing role of regions in the evolution of the international community and in the life of many modern states highlights the importance of the processes of regional development. These processes are manifested in the form of further development of regional integration, expansion of cross-border regional relations, and the emergence of regional areas of high development, where large financial, technological, and intellectual resources are concentrated. F. Perroux and J. Boudeville who developed the regional interpretation of growth poles and allocation of economic spaces made a great contribution to the theory of economic space. Scientific

Corresponding author:

${ }^{1}$ Department of Theoretical and Applied Economics, Vasyl Stefanyk Precarpathian National University.

E-mail: n-pysar@mail.ru 
works of S. S. Artobolevsky, O. V. Gritsay, V. N. Leksin, A. I. Treivish, A. N. Shvetsov and others are widely known. Such scientists-economists as O. I. Amosha, E. J. Blakely, Z. S. Varnalii, M. I. Dolishnii, Ya. A. Zhalilo, V. I. Zakharchenko, I. I. Lukinov, V. I. Muntiian, V. V. Tretiak, L. A. Yaremko, and others dealt with the problems of the regional economy. Studies of these scientistsarefocused on theresuscitationand development of the potential of the regions. However, these studies do not take into consideration market aspects of the development of regional economic space. Therefore, in the context of economic transformation, there is a need to clarify some theoretical positions of spatial development of economy and directions of forming an optimal model of development of the resource potential of the regional economy, and scientific development of these problems requires generalization, systematization and further development. Therefore, the aim of scientific work is to explore the imperatives for the effective development of the locally-spatial system, taking into account its resource potential, to determine possible ways of its implementation in the development of regional economic space and to ensure strategicguidelines and goals for socioeconomic development. The research task is to identify the necessary methodological foundations of improving regional development, to focus on the most influential directions in the theory of economic development in the region, to substantiate the conceptualization of an optimal model of economic development of the region. The methodological basis of this research is the dialectical method of cognition, systemic approach and fundamental provisions of economic theory and the theory of polarized space. The following research methods are applied: logical generalization, systemic and structural analysis, comparison, statistical, expert and others. The region represents the natural and socioeconomic system of unprecedented complexity. These systems are subject to natural and economic laws, are exposed to many diverse random factors, and are at risk to lose the balance of equilibrium. Therefore, for the study of complex systems, appropriate tools are required: the method of system analysis, economic and mathematical analysis, modelling, etc.

The news of the above-mentioned problems of the theory of productive forces and regional economy development, and the application of economic regulation of regional development and extending the scientific research range in this important area became the basis for the selection of research topics, identified the target and the list of priority tasks of the study, provided the expected results, scientific and practical achievements and elements of scientific novelty.

\section{The definition of polarized space}

The theory of spatial poles of economic growth and the theory of diffusion of innovations in a systematic interaction solve a problem of holistic and effective development of the regional economy: new technologies of the growth pole are a retranslator of innovations, diffusion of which contributes to the revitalization of underdeveloped areas.

The concept of spatial poles of economic growth takes the central place in the system of theories of regional development. The concept of spatial polarization has different interpretations, however, in general, it is "...a universal phenomenon in the regional economy that is a combination of objective and subjective factors that lead to excessive territorial variations in resource availability, methods and results of economic activity" (Ketova, 2006).

The need to develop theoretical and applied aspects of scientific problems of the development of socioeconomic system of the region in terms of spatial segregation and uneven economic processes can be supported by a set of interrelated arguments, one of which is the need for scientific substantiation of selection and identification of the resource potential that can play a role of an accelerator of the socioeconomic system development of the region, identify existing contradictions, and solve them.

An analysis of the development of the socioeconomic system of the Carpathian economic region in terms of spatial localization and unevenness of economic processes shows that a characteristic feature of the region is the presence of energy potential of the region. The region directly borders with the EU countries, other regions of Ukraine, it is crossed by several important highways that provide transit and connection with many countries. Paying attention to the geographical position of the Carpathian region, namely, the advantageous border location, it is shown that the Carpathian economic region needs a restructuring of those economy industries that have the most rapid turnover of funds, as well as export industries and agriculture. Therefore, in the short term, it is appropriate to conduct reconstruction, technical re-equipment of operating enterprises of light and food industry and the agro-industrial complex of the district. The Carpathian region is one of the largest in the provision of mineral and energy resources. An important task of integrated development is the increase in efficiency of fuel and energy and mineral complexes due to re-exploration and expansion of the resource base. The Carpathian region has forest resources in Ukraine.

Analysis of barriers on the way to the development of spatial local systems of the Carpathian economic region allowed the identification of resource potentials with the aim of identifying and addressing the key priority problems of the regional socioeconomic system as a whole, which can be grouped under the following headings: economic, social, institutional. 


\section{Possibilities for introducing the region polarization}

Principles for the introduction of the region polarization and the use of development potentials of the region are: compliance with economic efficiency of the use of regional resources for complex development of the region; balance of the parameters of economic development and life quality level of the population, a synchronous level of development of the real sector of the economy of the region, escalation of social infrastructure; adequacy of the applied methods and tools of regional management within the paradigm of adaptive and selective control; ensuring the dominance of social components over the desire to catalyse the processes of capital accumulation as the main efficiency criterion of the mechanisms of regional economic system management.

The use of these principles in the system of regional development allows updating several groups of immanent features of the development potentials of the region:

- System-modelling functions - facilitating in the formation and development of territorial and industrial complexes, clusters, units; optimal socio-economic zoning; and the development of ownership relations; formation of the effective mechanism of control; formation of rules, regulations, and standards etc.

- System-approving functions - development of local markets; wide application of the regional strategic programmes; development of infrastructural support; ensuring a positive image and reputation of the territory; compliance with policies of environmental and social responsibility etc.

- System-reproducing functions - rational distribution of economic resources; active use of spatial polarization smoothing tool; efficient use of natural resources and factors of production; regeneration of social and economic subsystems; protection and promotion of competition and entrepreneurship, etc.

- System-diagnostic functions - establishment of an effective monitoring system; search for "growth points" and "points of inefficiency" of the economy; forecasting and planning of the development of the region; creation of information-analytical system for bringing data and information on the market state to the final consumer; use of corrective control mechanisms, etc. (Zhukov, Dianova, 2012).

In general, it should be noted that each territory, regardless the composition of the natural resource base, overcomes several stages of development, with the inherent characteristics at each of them. Searching for the optimal combination of resources is carried out in a limited region of the allowed values and combination of them, while one of the factors will always be at the minimum, and other resources can be unused. The elements of resource potential that can be transformed into investment capital must be directed to increase the element that is the minimum that will lead to the emergence of new optimal combinations of resources and increase the balance of the entire system. Balanced resource potential is considered perfect when all resources can be involved in the process of economic activities of the region. If the optimal balance is not achieved, it is possible to talk about the space potential. To ensure a perfect balance of resource potential, resource approach to the development strategy of socio-economic system of the region in terms of spatial segregation and uneven economic processes is required.

\section{The need for activation of the points of regional development}

Activation of regional growth points will increase the efficiency of the organization of the regional management, efficient use of financial resources and focus regional resources on priority areas. Consideration of the forms of realization of the theory of growth poles and the conditions for the formation of the growth points in Ukraine has allowed identifying the main problems of activation of the regional growth points. Most often, the success of realization of the activation forms of growth points depends on the conditions, in which this implementation is: the border position of the region contributes to the successful formation of special economic zones and infrastructure contributes to the development of clusters and technology parks. Most regions of Ukraine do not have above-mentioned conditions and, consequently, cannot successfully implement different forms of activation of growth points with the existing regional management structures. In general, there are possible obstacles to effective implementation of activation forms of regional growth points:

- organizational: inefficient use of activation forms of regional growth points;

- investment: lack of opportunities to attract significant investment (the need to upgrade in the regions of outdated production assets of territorial and industrial complexes, lack of established infrastructure);

- financial: the absence of large financial flows (slow development of cluster formations, absence of major players in the regional market);

- innovation: lack of an effective mechanism for involving small business in innovation sphere (inability to promote the creation of small innovative entities, lack of an effective mechanism for the distribution of innovations among small businesses).

In modern conditions of economy functioning taking into account the specifics of regional development, an obvious need in search for, identification of primary key opportunities of the areas, and full use of their resource potential will ensure the economic sustainability of the region and competitiveness. 
The solution to the problem of complex assessment of the selected indicators in the search for new points of economic growth areas have to include the assessment of the basic resource potential: natural resources, geographic, recreational, socio-demographic, research and innovation; human, industrial, infrastructure and investment budget potential, and potential assessment of the regional readiness to implement a new strategic choice to conduct in the territory of the envisaged socio-economic transformations and activation of new economic growth points.

\section{Development concept of the spatial economic system}

Development concept of the spatial economic system of the region through the prism of the use of resource potentials is identified as a promising aim to overcome current limitations of the regional system and the presence of subjects-participants of the tactical tools system to achieve this ambitious goal.

Perspective resource and factor fullness of the Carpathian economic region and the concentration of the most valuable factors and resources at points of innovative growth are the imperatives of the process of formation and development of this commercial space organization form, and retrospective development aimed at production, transit, and sale of raw materials and energy resources and should change with prospective orientation on achievement of the following strategic goals: - intensive development of financial markets and human capital in the area of the macroregion; - creating necessary general conditions for approval of this innovative type of reproduction, energy independence development in case of more efficient and effective use of available resources.

The main directions of improvement of the spatial structure and territorial organization are: accelerating the implementation of state regional policy with the allocation of priorities of the territorial organization of economy of regions; restructuring of the economic base of individual regions and creation of conditions for recovery based on new technology; acceleration of the transformation on the basis of investment activities activation; improvement of legislative and normative base of regional development, which today is imperfect and fragmentary; monitoring introduction, system of control over financial flows to the regions of public funds (intergovernmental transfers, targeted subsidies, state investments, tax incentives, financing of target programs); improving the financial capacity of local public authorities and local governments for solving problems related to development areas; enhancing the efficiency of aggregate resource potential of the regions strengthening the role of the factors of economic growth; creating favourable conditions for the development of entrepreneurship, small and medium business, etc. Implementation of these areas will ensure the optimization of the territorial organization of regional economic systems, improving the efficiency of social production; accelerate the processes of the European integration and entering the country into the world community.

Key features of the concept of socio-economic growth poles (Artobolevsky, 2005):

- creating a socio-economic growth pole is not just a goal but a means of economic growth in the region, where the main goal of development is the moderation of territorial disparities in the life quality level of the population;

- growth pole can be effective only in the system of the same growth poles;

- growth pole must have close relationship with other settlements of the region to use its resources and transfer innovations and other impetuses;

- have to communicate between the country and the region;

- economic and social growth poles can be of different values and scale from international to local;

- the main aim of creating the socio-economic growth pole is to encourage self-development of regions and population centres.

\section{Conclusions}

On the basis of a generalization of the results of the analysis of the development of spatial economic systems of the regions, the best for them concept for the development of a spatial economic system, the strategy of diversification potentials, aimed at achieving the following long-term goals and results can be offered:

- improving the efficiency of use of available resources and factors of economic process;

- formation of new competitive types of businesses in the region;

- complex use of the opportunities of the national and international division of labour;

- acceleration of the socio-economic development of the region.

The main point in justifying the application of the underlying factors of diversification is highlighted. They allow making the socio-economic system of the region more open to outline a full range of potentials for its development. This circumstance is of primary importance in the solution of strategic objectives of overcoming spatial isolation and asymmetries in the economic process. The core of the strategic guidelines for the effective development of locally-spatial systems may be the concept of socio-economic development of the region. It is as imperative for long-term development, will be able to lead to a balanced level of spatially separate areas and implement strategic plans.

Conceptualization of modern regional development ability to provide systemic research of regional 
problems and possible methods of their solution is proposed. A consideration of theoretical foundations describes the features of regional development, allows penetrating deeply into the essence of economic phenomena and processes at the regional level. This will help to develop regional economy in accordance with major socio-economic trends, to build the console of the mechanisms of regional development at macro and microeconomic level, to regulate the development of the productive forces under the influence of factors of the information economy, to bring an element of the behaviour of economic agents into the development planning process. Further research will be focused on the development of an effective mechanism of innovation development of the economy of regions of Ukraine.

The study established the essential characteristics of economic regulation of regional development, in relation to the region as a territory, economic system, and economic space. Further development of theoretical provisions on the basic requirements of the effectiveness of economic regulation of regional development of the regions is based on the account and use the basic properties of the region as territory, economic system and economic space that allows giving the whole system properties such as complexity and integrity.

Practical value of the study is in the fact that theoretical provisions and conclusions obtained on the basis of theoretical generalizations are provided in the form of practical recommendations, namely improved: approaches to the definition of the spatiotemporal positioning of the regions of Ukraine in terms of economic development are based on the use of main and additional specific indicators that allows determining the advantages of each region over a relatively long period of time and also selecting leader and outsider groups from the entire set of objects.

\section{References:}

Ketova N.P., Ovchinnikov V.N. (2006). Regional economy: economic universal learning dictionary: 247 p. [in Russian]

Artobolevsky S.S. (2005). Regional development In terms of the emphasis can be arranged otherwise. [in Russian] [Electronic resource]. - Retrieved from: www.csr-nw.ru/upload/13.pdf

Zhukov, B. M., Dianova V.A. (2012). Identification of the resource development potential of the region. [in Russian] - [Electronic resource]. - Retrieved from: http://cyberleninka.ru/article/n/identifikatsiyaresursnogo-potentsiala-razvitiya-regiona

Mishenina, M. S. (2007). Polarization as the tendency in the development of economic space of the regions. Academic Bulletin, 1: 115-120. [in Russian].

Shary G. (2013). Spatial development of oil and gas complex: problems and prospects. The land management Bulletin,7:16-19. [in Ukrainian] - [Electronic resource]. - Retrieved from: http://nbuv.gov.ua/UJRN/ Zv_2013_7_8

Zinovieva A.A. (2011). The problems of smoothing of spatial polarization in the regional economy. Problems of modern economy, 4. [in Russian].

Vatchenko O.B. (2011). The theoretical justification of regional policy. Regional economy, 3: 27- 34. [in Ukrainian] Vozniak H. V. (2015). Modern theories and paradigms of regional development: the practical aspect for Ukraine. Global and national problems of Economics, 5: 671- 677. [in Ukrainian]

Danylyshyn B.M., Cherniuk L.H., Faschevs'kyj M.I. (2007). Spatial organization of the productive forces of Ukraine: meso - and mcsorely level. 572 p. [in Ukrainian]

Dehtiar'ova I. (2010). Theories of regional development and their evolution as the basis of modern regional control. Visn. NADU, 4: 141-148. [in Ukrainian]

Medvid' V.Yu. (2013). Modern concepts and theories of regional economic development. Seriia: Economics and entrepreneurship, 2 (71): 66-70. [in Ukrainian]

Prykhodchenko T.A. (2016). Theories and concepts of regional development Elektronne naukove fakhove vydannia "Effective ekonomy", 9. [in Ukrainian]

Pel'tek L.V. (2010). The development of the regional industrial policy of the state: the theory, methodology, mechanisms. Monograph. Vyd-vo ChDU im. Petra Mohyly, 268 p. [in Ukrainian].

\section{Надежда ПИСАРЬ}

КОНЦЕПЦИЯ ФОРМИРОВАНИЯ ПОЛЯРИЗОВАННОГО ПРОСТРАНСТВА В ЭКОНОМИКЕ РЕГИОНА С РЕСУРСНЫМ ПОТЕНЦИАЛОМ

Аннотация. В статье систематизированы и проанализированы теории и парадигмы регионального развития. Определены возможности оптимального развития региональной экономики в Украине, так как функционирование рыночной системы сопровождается кризисными явлениями и требует глубокого научного изучения современной экономической теории и практики выхода из кризиса с применением инновационных концепций развития региона. Концепция поляризованного пространства в экономике 
регионов Украины с определением мер по ее внедрению является важным и недостаточно разработанным научным исследованием. Результатом трансформационных экономических преобразований в национальной экономике стало доминирование так называемого "точечного развития". Несмотря на положительный эффект от присутствия на отдельной территории полюсов роста, эта ситуация усиливает асимметричность в экономическом развитии по сравнению с другими территориями. Следствием этого становится дифференциация основных экономических и социальных показателей экономического регионального развития.Всвязи сэтим изучениерегиональных концепций итеорийэкономического регионального развития составляет актуальное теоретическое и практическое задание, ведь отсутствие единого подхода к основ теории экономического пространства, и особенно ее региональной составляющей, не позволяет приступить к решению ряда практических проблем системного формирования единого экономического пространства страны. Данные проблемы ставят множество вопросов прикладного характера, на которые экономическая теория не всегда может дать однозначный ответ. Подобные вопросы имеют, безусловно, теоретический интерес, но главное- ответы на них могут способствовать формированиюэффективной конкурентоспособной экономики региона. Объектом исследования являются регионы Украины с их ресурсным потенциалом и отсутствующим поляризованным пространством. Основной задачей является формирование на этой основе антикризисных мер развития региона. Предметом исследования являются теоретические положения и методология формирования поляризованного пространства с низким качеством экономического пространства. Методологической базой исследования является диалектический метод познания, системный подход, фундаментальные положения экономической теории и теории поляризованного пространства. Применяются следующие методы исследования: логического обобщения, системно-структурного анализа, сравнения, статистические, экспертные и т. д. Цель заключается в исследовании императивы эффективного развития локально-пространственной системы с учетом ее ресурсного потенциала, определение возможных путей его реализации в целях развития регионального экономического пространства и обеспечения стратегических ориентиров и целей социально-экономического развития. Полученные результаты дали возможность определить необходимые методологические основы совершенствования регионального развития, сделать акцент на наиболее влиятельных направлениях в теории развития экономики региона, обосновать концептуализацию оптимальной модели развития экономики региона. 